\title{
Parental satisfaction with nursing professionalism in paediatric surgical departments - a preliminary report
}

\section{Satysfakcja rodziców z profesjonalizmu opieki pielęgniarskiej na oddziałach chirurgii dziecięcej - doniesienia wstępne}

\author{
Agnieszka Kruszecka-Krówka, Grażyna Cepuch, Krystyna Twarduś, Magdalena Wójtowicz, \\ Agnieszka Gniadek
}

Nursing and Midwifery Institute, Faculty of Health Sciences, Jagiellonian University Medical College, Krakow, Poland Head of the Institute: Agnieszka Gniadek PhD, Prof. UJ

Key words: nursing care, child, professionalism, satisfaction with care, parent.

Słowa kluczowe: opieka pielęgniarska, dziecko, profesjonalizm, satysfakcja z opieki, rodzic.

\begin{abstract}
Introduction: Nurses' professionalism is an important component of the assessment of childcare quality during hospitalisation.

Aim of the research: Assessment of parental satisfaction with the professionalism of nursing care in paediatric surgical departments.

Material and methods: The cohort study was conducted in a group of 127 parents of children hospitalised in surgical departments. The Polish adaptation of the Emphatic questionnaire and the original questionnaire were applied in the study. Results: The median of overall parental satisfaction with child nursing professionalism was 4.3 (3.8; 4.7$)$. A low level of satisfaction with nursing care in the specific criteria was observed only for The nurse introduced herself by name: 2.0 (1.0; 3.0$)$. Statistical significance was demonstrated between the overall level of parental satisfaction with care regarding Professional Attitude and the reason of the child's hospitalisation $(p=0.017)$ as well as the number of children in a family $(p=0.001)$. The child's developmental stage, the mode of admission to hospital, and the parents' sex differentiated parental satisfaction regarding selected components of the professionalism of nursing care $(p<0.05)$. The strongest relationships were demonstrated between the level of overall satisfaction for Professional attitude and the satisfaction level for the specific criterion The nurse greeted the parents/guardians kindly at admission/visits (rho $=0.803)$.

Conclusions: A high level of parental satisfaction with nurses' professionalism was observed. The optimization of care is especially needed in the area of nurses introducing themselves. The determinants of the level of overall satisfaction were as follows: the reason for hospitalisation, the number of children in a family, and the attitude of the nursing team.
\end{abstract}

\section{Streszczenie}

Wprowadzenie: Profesjonalizm pielęgniarek jest istotnym elementem oceny jakości opieki nad dzieckiem w czasie hospitalizacji.

Cel pracy: Ocena satysfakcji rodziców z profesjonalizmu opieki pielęgniarskiej na oddziałach chirurgii dziecięcej.

Materiał i metody: Badanie kohortowe przeprowadzono w grupie 127 rodziców dzieci hospitalizowanych na oddziałach chirurgii dziecięcej. W badaniu wykorzystano kwestionariusz Empathic autorstwa Latour i wsp. w polskiej adaptacji, a także kwestionariusz autorski.

Wyniki: Mediana poziomu ogólnej satysfakcji rodziców z profesjonalizmu opieki pieleggniarskiej wyniosła 4,3 $(3,8 ; 4,7)$. Niski poziom satysfakcji rodziców w zakresie kryteriów szczegółowych wykazano jedynie dla kryterium Pielęgniarka przedstawiła się z imienia i nazwiska: $2,0(1,0 ; 3,0)$. Stwierdzono istotność statystyczną pomiędzy poziomem ogólnej satysfakcji rodziców z opieki pielęgniarskiej w kryterium Profesjonalizm/Profesjonalne podejście a przyczyną hospitalizacji dziecka $(p=0,017)$ oraz liczbą posiadanych dzieci $(p=0,001)$. Okres rozwojowy dziecka, tryb przyjęcia dziecka do szpitala, a także płeć rodziców istotnie statystycznie różnicowały satysfakcję w wybranych elementach profesjonalizmu opieki pielęgniarskiej $(p<0,05)$. Najwyższy stopień związku uzyskano pomiędzy ogólnym poziomem satysfakcji w zakresie kryterium Profesjonalizm/Profesjonalne podejście a poziomem satysfakcji dla kryterium szczegółowego Pielęgniarka miło witała rodziców/opiekunów przy przyjęciu/odwiedzinach ( $\mathrm{rho}=0,803$ ).

Wnioski: Poziom satysfakcji rodziców z profesjonalizmu opieki pielęgniarskiej był wysoki. Optymalizacja opieki jest szczególnie potrzebna w obszarze przedstawiania się przez pielęgniarki. Czynnikami determinującymi ogólny poziom satysfakcji z opieki były: przyczyna hospitalizacji, liczba posiadanych dzieci oraz postawa zespołu pielęgniarskiego. 


\section{Introduction}

One of the main goals of contemporary health care institutions is to ensure a high quality of the services provided. Quality is perceived as the key determinant of attractiveness of services and products as well as of providers' competitiveness $[1,2]$. The quality of care is assessed both by service providers, i.e. medical staff, management of medical institutions, politicians, local governments, and payers, and by service recipients, i.e. patients and their families [3-6]. For patients and their families, the quality of medical services primarily means a subjective perception of satisfaction with the care received [6, 7].

Satisfaction with care is a leading indicator of its quality [8], and it is the difference between patients' expectations regarding services and the real care provided. It concerns subjective experiences related to a feeling of being satisfied and acceptance of the care, which are manifested by the attitudes, reactions, and behaviours of service recipients and their families/parents/guardians involved in the hospitalisation process $[7,9,10]$. Satisfaction with care is a multidimensional concept affected by individual, systemic, and cultural factors [10]. Patients and/or their families express their opinions on health services based on subjective values, needs, expectations, and previous experience related to hospital stay as well as the treatment and nursing process [7, 9-11]. According to Matziou et al. [11], the opinion of patients and their families is particularly valuable in terms of the assessment of the interpersonal aspect of care which is based on the occupational professionalism of the medical staff, including the nursing team.

The obligation of professional nursing care provision is established in the primary legal ethical acts and codes of ethics that regulate the professions of nurses and midwives in Poland and guarantee the patient's rights in health care institutions [12-14]. Professionalism in nursing encompasses knowledge, skills, and responsibility in the process of health service provision. Being an important component of patients' satisfaction assessment concerning services received, it includes the aspect of work organisation, collaboration of therapeutic team members, nurses' clinical competence [10, 15-17], the professional group's image [18], conditions of hospital admission, facilities, availability of service, the length of waiting time for a service, support, empathy, respect, as well as protection of the privacy of patients and their families [19-21].

To date, research regarding parental satisfaction with child nursing professionalism conducted in Poland has been conducted primarily using original research instruments [22, 23]. Research with the standardised Empathic questionnaire has been conducted by Smoleń and Ksykiewicz [16, 21] and Kruszecka-Krówka et al. [1], highlighting a high average level of parental satisfaction with this aspect of care in paediatric departments. Also, the authors $[1,16,21]$ differentiated the areas where the care needed optimisation. In Poland, we lack studies aimed at the assessment of parental satisfaction with nursing care professionalism in paediatric surgical departments based on a standardised research instrument. Considering the specificity of paediatric nursing work on surgical wards, reasons for children's admission to surgical departments, the specific situation of children and parents during the peri-operative period, and the significance of the interpersonal aspect of nursing services for the overall assessment of satisfaction of patients and their families with the hospital stay, it is important to conduct scientific research also in this area of surgical nursing [1,22]. Knowledge of the level of parental satisfaction and identification of satisfaction predictors regarding nursing professionalism will ensure better understanding of service recipients' expectations as well as optimisation of services in paediatric surgical departments [16], thus contributing to achievement of better long-term health outcomes in children and promotion of a health care unit $[9,11,17]$.

\section{Aim of the research}

The aim of the study was the assessment of parental satisfaction with child nursing professionalism in paediatric surgical departments, with its potential predictors.

\section{Material and methods}

\section{Study design}

The research had a cohort study nature, carried out using the method of a diagnostic survey. The selection of the study group was purposeful. The research was carried out as a part of the statutory project Parental satisfaction with nursing care in paediatric wards (N43/ DBS/000092) conducted in Polish. Part of the statutory project results has already been published [1].

The research instruments were the Empathic questionnaire developed by Latour et al. [20], adapted to the Polish setting by Smoleń and Ksykiewicz [24], and an original questionnaire.

The Empathic standardised questionnaire measures overall satisfaction with nursing care and satisfaction with child nursing in terms of 5 major criteria: I. Information, II. Care and Treatment, III. Availability, IV. Parental Participation, and V. Professionalism/ Professional Attitude, containing 2 to 19 specific assigned criteria. The score for each of the major criteria was a mean of the scores for the specific assigned criteria. For the research purposes, the V. Professionalism/Professional Attitude part of the questionnaire, containing 19 specific criteria, was applied. Each of the specific criteria was assessed by the parents using a 5-point Likert scale where a score of 1 denoted "I am very dissatisfied" and 5 meant "I am very satisfied". 
The satisfaction score was expressed as point values with the accuracy of 2 decimal places. The score of 1 to 2.5 denotes a low level of satisfaction with nursing care (overall, for the major criteria and for each specific criterion). The score of 2.6 to 4 corresponds to the medium level of satisfaction with care. A high level of satisfaction with nursing care is considered to score 4.1 to 5 points.

An original questionnaire included such selected variables as the following: the age of hospitalised child; mode of hospital admission; reason of hospitalisation; hospital stay length; age, sex, and the education level of the parents; and the number of children in the family.

Age-related categories for the children in the study corresponded to paediatric developmental stages [25], and the parents' age categories were as follows: below 30 years, 30 to 40 years, or above 40 years of age. The parents reported one of the following reasons for the child's hospitalisation: chronic disease exacerbation, sudden illness, diagnostic assessment, cancer therapy, or surgery. Emergency or elective admissions to hospital were also included in the questionnaire.

\section{Setting and sample}

The study was conducted in the year 2019 among 127 parents of children staying on the surgical wards of the Paediatric Surgical Clinic at the University Children's Hospital of Cracow. Having received the hospital discharge summary, the parents (being the primary caregiver during the child's hospital stay and willing to participate in the study) completed survey questionnaires.

A total of 180 questionnaires were distributed, and 127 questionnaires were received back (survey response rate $70.56 \%$ ), of which all questionnaires were fully completed. Thus, 127 people were included in the analysis of data.

The inclusion criteria were as follows: 24 -hour or temporary (but not shorter than $12 \mathrm{~h}$ /day) presence of the parent with the child during the stay in the paediatric surgical department, at least 3-day hospitalisation and voluntary participation, Polish Nationality or other nationality but good knowledge of Polish in speech and writing. The exclusion criteria were as follows: unwillingness to participate in the study, less than 3-day duration of hospital stay, absence of parents during the child's hospitalisation or a temporary stay with the child for less than 12 hours per day or the child's end-of-life stage, and other than Polish Nationality and no knowledge of Polish language.

\section{Ethical considerations}

The study was approved by the Bioethics Committee at the Jagiellonian University (no. 122.6120.254.2016), the director of the hospital, the head of the Paediatric Surgical Department, and the parents. The study was conducted in accordance with the ethical principles set in the Declaration of Helsinki. The parents' participation was voluntary and anonymous. They provided informed consent.

\section{Statistical analysis}

Distributions of specific variables were compared to the normal distribution by means of the Kolmogorov-Smirnov test. Because the quantitative variables were far from the normal, the analyses were primarily based on nonparametric tests: $U$ MannaWhitney (for 2 samples) and Kruskal-Wallis (for more than 2 samples). After detection of statistically significant differences, post-hoc analysis was performed using the Bonferroni correction for multiple comparisons. Statistical characteristics of categorical variables were shown as absolute numbers and percentages. Statistical characteristics of quantitative variables were presented as median and upper and lower quartile. Spearman's correlation was used for quantitative/ ordinal variables. The significance level was set as $p \leq 0.05$.

\section{Results}

\section{Characteristics of the study group}

The study group consists of 127 parents: 83\% women and $17 \%$ men. The median respondents' age was 34 years $(29 ; 40)$, and $47.2 \%$ of all respondents were in the group aged 30 to 40 years. A higher education level was declared by $63 \%$ of the surveyed. Almost a half of the respondents $(48 \%)$ were parents with 2 children.

Parents of neonates or infants constituted $37.8 \%$ of the surveyed. The smallest number of respondents $(8.7 \%)$ had children at puberty. The dominant admission mode was emergency admission $-61.4 \%$ of the patients. The most common reason of hospitalisation was sudden illness, reported by $52.8 \%$ of the surveyed. Over $29.1 \%$ of the patients were admitted to the ward for surgery. The median length of hospital stay was 5 days $(3 ; 9)$. The demographic and clinical characteristics of the sample are summarized in Table 1.

\section{Parental satisfaction with the professionalism} of nursing care in surgical departments

The median overall parental satisfaction with child nursing professionalism was 4.3 (3.8; 4.7). A low level of satisfaction with nursing care was observed only for The nurse introduced herself by name: 2.0 (1.0; 3.0). A medium level of satisfaction with care was noted for The parents knew which nurse was taking care of their child: 4.0 (3.0; 5.0), Accommodation for the parents at a location near the department was ensured: 3.0 (1.0; 5.0), The nurse demonstrated empathy for the parents/ guardians: 4.0 (3.0; 5.0), The nurse greeted the parents/ guardians kindly at admission/visits: 4.0 (3.0; 5.0), and 
Table 1. Characteristics of the study group

\begin{tabular}{|c|c|c|c|}
\hline \multicolumn{2}{|c|}{ Sociodemographic variables of the surveyed } & \multirow{2}{*}{$\begin{array}{c}N \\
105\end{array}$} & \multirow{2}{*}{$\begin{array}{c}\% \\
82.7\end{array}$} \\
\hline Sex & Female & & \\
\hline & Male & 22 & 17.3 \\
\hline \multirow[t]{3}{*}{ Age } & Below 30 years old & 44 & 34.6 \\
\hline & 30 to 40 years old & 60 & 47.2 \\
\hline & Above 40 years old & 23 & 18.1 \\
\hline \multirow[t]{2}{*}{ Education level } & Higher & 80 & 63.0 \\
\hline & Other than higher & 47 & 37.0 \\
\hline \multirow[t]{3}{*}{ Number of children } & 1 & 45 & 35.4 \\
\hline & 2 & 61 & 48.0 \\
\hline & At least 3 & 21 & 16.5 \\
\hline \multirow[t]{4}{*}{ Child's developmental stage } & Newborn and infant & 48 & 37.8 \\
\hline & Toddler & 21 & 16.5 \\
\hline & Preschool & 22 & 17.3 \\
\hline & Early school and puberty & 36 & 28.4 \\
\hline \multirow[t]{2}{*}{ Mode for the child's hospital admission } & Emergency & 78 & 61.4 \\
\hline & Elective & 49 & 38.6 \\
\hline \multirow[t]{3}{*}{ Reason for the admission } & Sudden illness & 67 & 52.8 \\
\hline & Surgery & 37 & 29.1 \\
\hline & Other & 23 & 18.1 \\
\hline \multirow[t]{2}{*}{ Co-morbidities } & Yes & 16 & 12.6 \\
\hline & No & 111 & 87.4 \\
\hline \multirow[t]{3}{*}{ Length of the child's hospital stay } & Up to 7 days & 84 & 66.1 \\
\hline & $8-14$ days & 26 & 20.5 \\
\hline & More than 14 days & 17 & 13.4 \\
\hline \multirow[t]{2}{*}{ Hospital stay } & First & 105 & 82.7 \\
\hline & Further & 22 & 17.3 \\
\hline
\end{tabular}

$n$ - number of valid answers, \% - percentage rate of valid answers.

A change in the atmosphere at work did not affect the level of nursing services provided to the child: $4.0(4.0 ; 5.0)$. Parental satisfaction with nursing care regarding other criteria was high (Table 2).

Parental satisfaction with the professionalism of nursing care vs. the child's developmental stage and the reason for hospitalisation

The child's developmental stage did not diversify the level of overall satisfaction for Professional Attitude $(p=0.774)$, except for the specific criteria: Collaboration in the medical and nursing team was seen ( $p=0.047)$, The written information about the rules of department functioning was available in a location easily accessed by the parents ( $p=0.049)$, The nurse protected the child's privacy ( $p=0.037)$, and The nurse protected the privacy of parents/guardians $(p=0.028)$. Multiple comparisons indicated a lower level of toddlers' parents' satisfaction compared to parents of newborns and infants in all criteria ( $p<0.05)$ and compared to preschoolers' parents in the criterion The nurse protected the privacy of parents/guardians ( $p=0.044)$.

The reason for hospitalisation differentiated the level of satisfaction with Professional Attitude $(p=0.013)$ and with the specific criteria: The parents/guardians knew which nurse was taking care of their child ( $p=0.009)$, There were flexible visiting hours in the department $(p=0.003)$, The nurse protected the child's privacy $(p=0.017)$, The nurse refrained from unnecessary comments at the child's bed $(p=0.016)$, The nurse demonstrated empathy for the child $(p=0.003)$, The nurse demonstrated empathy for the parents/guardians ( $p=0.006)$, and The nurse greeted the parents/guardians kindly at admission/visits $(p=0.017)$. The parents of children admitted to hospital for surgery 
Table 2. Parental satisfaction with the professionalism of nursing care in paediatric surgical wards

\begin{tabular}{|c|c|c|c|}
\hline Professional attitude & Me & Q1 & Q3 \\
\hline 1. Collaboration in the medical and nursing team was seen & 5.0 & 4.0 & 5.0 \\
\hline 2. The parents/guardians knew which nurse was taking care of their child & 4.0 & 3.0 & 5.0 \\
\hline 3. The nurse introduced him/herself by name & 2.0 & 1.0 & 3.0 \\
\hline 4. The on-duty nurse's work was well organised & 5.0 & 4.0 & 5.0 \\
\hline 5. The nursing team's work ensured the child the sense of security & 5.0 & 4.0 & 5.0 \\
\hline 6. The child's immediate environment was clean & 5.0 & 5.0 & 5.0 \\
\hline $\begin{array}{l}\text { 7. The written information about the rules of department functioning was available in } \\
\text { a location easily accessed by the parents }\end{array}$ & 5.0 & 4.0 & 5.0 \\
\hline 8. There were flexible visiting hours in the department & 5.0 & 4.0 & 5.0 \\
\hline 9. Accommodation for the parents at a location near the department was ensured & 3.0 & 1.0 & 5.0 \\
\hline $\begin{array}{l}\text { 10. The nurse ensured high-quality care regardless of the race, religion, sex, and education } \\
\text { level of the parents }\end{array}$ & 5.0 & 4.0 & 5.0 \\
\hline 11. The nurse protected the child's privacy & 5.0 & 4.0 & 5.0 \\
\hline 12. The nurse protected the privacy of parents/guardians & 5.0 & 4.0 & 5.0 \\
\hline 13. The nurse demonstrated respect for the parents/guardians & 5.0 & 4.0 & 5.0 \\
\hline 14. The nurse refrained from unnecessary comments at the child's bed & 5.0 & 4.0 & 5.0 \\
\hline 15. The nurse demonstrated empathy for the child & 5.0 & 4.0 & 5.0 \\
\hline 16. The nurse demonstrated empathy for the parents/guardians & 4.0 & 3.0 & 5.0 \\
\hline 17. The nurse greeted the parents/guardians kindly at admission/visits & 4.0 & 3.0 & 5.0 \\
\hline $\begin{array}{l}\text { 18. A change in the atmosphere at work did not affect the level of nursing services provided } \\
\text { to the child }\end{array}$ & 4.0 & 4.0 & 5.00 \\
\hline 19. The child's health was the highest priority for the nurse & 5.0 & 4.0 & 5.00 \\
\hline $\begin{array}{l}\text { Overall satisfaction regarding the criterion } \\
\text { Professional attitude }\end{array}$ & 4.3 & 3.8 & 4.7 \\
\hline
\end{tabular}

Me - median, Q1 - lower quartile, Q3-upper lower quartile.

expressed a higher level of overall satisfaction with Professional Attitude compared to the parents of children with sudden illness $(p=0.010)$ : $4.6(4.1 ; 4.8)$ vs. $4.2(3.6$; 4.6), and a higher level of satisfaction in all specific criteria $(p<0.05)$.

The presence of co-morbidities in children did not diversify parental satisfaction with care $(p>0.05)$.

\section{Parental satisfaction with the professionalism of nursing care vs. the mode of child's admission to hospital and the length of hospital stay}

The mode of child's admission to hospital did not differentiate the overall parental satisfaction with Professional Attitude ( $p=0.068$ ). In terms of the specific criteria, such as: The nurse refrained from unnecessary comments at the child's bed $(p=0.006)$, The nurse demonstrated empathy for the child ( $p=0.044)$, and The nurse demonstrated empathy for the parents $(p=0.033)$, a higher level of parental satisfaction was obtained in a group with elective admission than emergency.
Statistically significant differences were not observed for both the overall parental satisfaction with Professional Attitude and the satisfaction scores for all the specific criteria regarding the length of child's hospital stay and the first-time and further children's admissions $(p>0.05)$.

Parental satisfaction with the professionalism of nursing care vs. the parents' sex, age, education level, and the number of their children

Statistical significance was not demonstrated between the parents' sex and the level of overall satisfaction for Professional Attitude ( $p=0.174$ ), except for the specific criteria The on-duty nurse's work was well organised $(p=0.049)$ and The nurse demonstrated empathy for the child ( $p=0.044)$, where a higher score of satisfaction level was observed among women compared to men: $5.0(4.0 ; 5.0)$ vs. $4.0(3.0 ; 5.0)$.

The parents' age did not differentiate the level of overall satisfaction for the major criterion Profes- 
sional Attitude $(p=0.231)$. Statistical significance was only demonstrated for the specific criterion The parents knew which nurse was taking care of their child ( $p=0.023)$; here the parents above 40 years of age expressed higher level of satisfaction compared to the parents $30-40$ years of age $(p=0.018): 5.0(4.0 ; 5.0)$ vs. $4.0(3.0 ; 5.0)$.

Statistically significant differences were not observed between the parents' education level and the median level of satisfaction for both the major criterion Professional Attitude and each of the specific criteria $(p>0.05)$.

However, statistical significance was observed between the number of children and the median level of satisfaction with care for the major criterion Professional Attitude ( $p=0.001$ ) and for the specific criteria, such as The parents knew which nurse was taking care of their child ( $p=0.027)$, The on-duty nurse's work was well organised ( $p=0.020)$, The nursing team's work ensured the child the sense of security ( $p=0.008)$, Accommodation for the parents at a location near the department was ensured ( $p=0.045)$, The nurse ensured high-quality care regardless of the race, religion, sex and education level ( $p=0.001)$, The nurse refrained from unnecessary comments at the child's bed $(p=0.026)$, The nurse demonstrated empathy for the child ( $p=0.008)$, The nurse demonstrated empathy for the parents ( $p=0.003)$, and The nurse greeted the parents/ guardians kindly at admission/visits ( $p=0.009)$. Multiple comparisons demonstrated a lower level of overall satisfaction in a group with 1 child than at least 3 ( $p=$ $0.001)$ : 3.9 (3.6; 4.5$)$ vs. $4.7(4.3 ; 4.9)$. The parents with at least 3 children were also more satisfied than the parents with 1 child in all specific criteria $(p<0.05)$ and more satisfied than the parents with 2 children in The nurse demonstrated empathy for the child ( $p=0.026)$ and The nurse demonstrated empathy for the parents $(p=0.013)$.

\section{Parental satisfaction concerning specific criteria vs. overall satisfaction with the professionalism of nursing care}

The highest relationships were observed between the overall satisfaction level for Professional Attitude and the satisfaction levels for The nurse greeted the parents/guardians kindly at admission/visits (rho $=0.803$ ) and The nursing team's work ensured the child the sense of security (rho $=0.791$ ).

The lowest, although still moderately strong, relationship was seen for the overall satisfaction level regarding Professional attitude and the criteria The child's immediate environment was clean $(\mathrm{rho}=0.431)$ and The nurse introduced herself by name $(\mathrm{rho}=0.476)$; see Table 3 .

\section{Discussion}

Assessment of the nursing team's professionalism is an important component of evaluation of parental satisfaction with child nursing, determining the over- all perception of health services received during hospitalisation [16, 19]. Professionalism in nursing care encompasses knowledge, skills, and responsibility for professional tasks [16]. In our study, a high level of overall parental satisfaction with the professionalism of nursing care was observed. Statistical significance was demonstrated between the overall level of parental satisfaction with nursing care regarding Professional attitude and the reason of the child's hospitalisation as well as the number of children in a family. The child's developmental stage, the mode of admission to hospital, and the parents' sex differentiated parental satisfaction in a statistically significant manner regarding selected components of the professionalism of nursing care. The strongest relationships were demonstrated between the level of overall satisfaction for Professional attitude and the satisfaction level for the specific criterion The nurse greeted the parents/guardians kindly at admission/visits.

The high level of parental satisfaction found from this study was consistent with results of other authors who conducted research based on the Polish adaptation of the Empathic questionnaire [1, 16, 21] or the original survey questionnaire [22]. The lowest level of respondents' satisfaction was associated with the criterion regarding nurses introducing themselves by name, similarly to the findings of Smolen and Ksykiewicz [16] as well as Kruszecka-Krówka et al. [1]. A relatively low level of respondents' satisfaction was observed for The parents knew which nurse was taking care of their child. A lack of medical team members' practice of introducing themselves by name to patients and their families may affect their sense of security, increase disorientation, and generate negative emotions. Kazimierczak et al. also reported the above problem: $79 \%$ of nurses admitted they did not introduce themselves to patients and their families, and only 33\% of the medical team's members declared they wore ID badges [22]. Making the medical team's members aware of the importance of introducing themselves by name and function to service recipients is probably a factor that will improve perception of nursing care, support the sense of security during hospitalisation, and contribute to building a positive image of the professional group [1].

Parental satisfaction with nursing care may have a multifactorial dimension. The child's age or developmental stage is indicated as a universal predictor of satisfaction with health services during hospitalisation $[1,11,19]$. Greater difficulties for younger children in adapting to the process of hospitalisation, a larger scope of parental participation in care, and enhanced separation anxiety in these patients may generate parents' higher needs and expectations regarding nursing care, resulting in a lower level of satisfaction with the services received $[1,11,26]$. The results of our research did not indicate a relationship between the child's developmental stage and overall 
Table 3. Parental satisfaction concerning specific criteria vs. overall assessment of satisfaction with the professionalism of nursing care $(n=127)$

\begin{tabular}{|c|c|c|}
\hline \multirow{3}{*}{$\begin{array}{l}\text { Satisfaction } \\
\text { Specific criteria }\end{array}$} & \multirow{2}{*}{\multicolumn{2}{|c|}{$\begin{array}{c}\text { Overall satisfaction } \\
\text { Professional attitude }\end{array}$}} \\
\hline & & \\
\hline & rho & $P$-value \\
\hline 1. Collaboration in the medical and nursing team was seen & 0.596 & $<0.001$ \\
\hline 2. The parents/guardians knew which nurse was taking care of their child & 0.737 & $<0.001$ \\
\hline 3. The nurse introduced him/herself by name & 0.476 & $<0.001$ \\
\hline 4. The on-duty nurse's work was well organised & 0.742 & $<0.001$ \\
\hline 5. The nursing team's work ensured the child the sense of security & 0.791 & $<0.001$ \\
\hline 6. The child's immediate environment was clean & 0.431 & $<0.001$ \\
\hline $\begin{array}{l}\text { 7. The written information about the rules of department functioning was available } \\
\text { in a location easily accessed by the parents }\end{array}$ & 0.545 & $<0.001$ \\
\hline 8. There were flexible visiting hours in the department & 0.521 & $<0.001$ \\
\hline 9. Accommodation for the parents at a location near the department was ensured & 0.567 & $<0.001$ \\
\hline $\begin{array}{l}\text { 10. The nurse ensured high-quality care regardless of the race, religion, sex and } \\
\text { education level of the parents }\end{array}$ & 0.674 & $<0.001$ \\
\hline 11. The nurse protected the child's privacy & 0.712 & $<0.001$ \\
\hline 12. The nurse protected the privacy of parents/guardians & 0.714 & $<0.001$ \\
\hline 13. The nurse demonstrated respect for the parents/guardians & 0.730 & $<0.001$ \\
\hline 14. The nurse refrained from unnecessary comments at the child's bed & 0.665 & $<0.001$ \\
\hline 15. The nurse demonstrated empathy for the child & 0.754 & $<0.001$ \\
\hline 16. The nurse demonstrated empathy for the parents/guardians & 0.778 & $<0.001$ \\
\hline 17. The nurse greeted the parents/guardians kindly at admission/visits & 0.803 & $<0.001$ \\
\hline $\begin{array}{l}\text { 18. A change in the atmosphere at work did not affect the level of nursing services } \\
\text { provided to the child }\end{array}$ & 0.740 & $<0.001$ \\
\hline 19. The child's health was the highest priority for the nurse & 0.670 & $<0.001$ \\
\hline
\end{tabular}

$n$ - number of valid answers, rho - Spearman's rank correlation coefficient, $p$ - 2-sided significance.

parental satisfaction with the care professionalism, which is consistent with the reports of Smolen and Ksykiewicz [16, 21]. However, statistical significance was obtained for several of the specific criteria of professionalism. Also, other authors presented different conclusions [1, 27] proving that older child's age was associated with a higher level of parental satisfaction with the services provided in non-surgical departments and a lower satisfaction level concerning information, a procedure of hospital discharge, and care availability on surgical wards $[19,28]$. The differences between our findings and those of individual authors may be explained, e.g., by the use of different research instruments $[19,27,29]$ and the presence of factors that were not included in research, such as the child's clinical status, the level of pain perceived $[11,28]$, or the emotional state of the patient/parents [29], which may have determined the levels of service acceptance and satisfaction with care. Thus, there is a rationale for unifying instruments to obtain the most reliable results of analyses and planning multidirectional research with other potential predictors of parental satisfaction.

The length of hospital stay did not differentiate the respondents' satisfaction with nursing professionalism. On the other hand, Smolen and Ksykiewicz observed a statistically significant higher level of overall satisfaction [16] as well as of the satisfaction with information and nurse availability [21] among the parents of children hospitalised for longer than 28 days. Moreover, a longer hospital stay was an important predictor of a higher level of parental satisfaction with care in the study conducted by Divecha et al. [30]. Longer hospitalisation seems to result in better adaptation of patients and their parents to the hospital stay, which may result in a higher level of satisfaction with the services received [11]. However, the longest hospitalisation in surgical departments usually refers to children with serious health problems and those with treatment complications [1]. Therefore, it 
cannot be excluded that the positive final outcome of nursing care in this group of patients could determine the higher level of satisfaction with the attitude of the nursing team towards the parents/guardians. Considering the fact that scientific reports are not consistent for this issue $[1,16,29,30]$, inclusion of the above aspects in further studies would be beneficial.

The analysis of literature regarding parental satisfaction with nursing care indicates a higher level of satisfaction with care or its selected criteria among parents of electively admitted children [1, 21]. According to Bednarek and Machul [23], 45\% of nurses think that elective hospitalisation favours adaptation of paediatric patients to the hospital stay and it enables appropriate mental and physical preparation of children and/or parents for the hospital stay and treatment $[1,9,31]$. It is particularly important when a child is hospitalised in a surgical department and managed during the peri-operative period, leading to reduced negative emotions of both the child and the family. However, our findings showed that the elective mode of the child's admission to hospital determined higher parental satisfaction with nurses' professionalism only for the criterion of nurses refraining from unnecessary comments at the patient's bed and demonstrating empathy.

The highest level of satisfaction with care was seen among the parents of children admitted to hospital for surgery. Scientific reports of other authors [1,21] show varied outcomes in this domain. Smolen and Ksykiewicz [21] did not observe any relationship between the level of satisfaction with care and the reason of hospitalisation, while Kruszecka-Krówka et al. [1] demonstrated a statistically significant lower level of satisfaction concerning information among the parents of children admitted to hospital due to injuries. On the other hand, Matziou et al. [11] and Willebrand et al. [19] highlight a correlation between parental satisfaction with care and their perception of the child's clinical status at admission. In the cited reports [11, 19], parents perceiving their children's situation as serious and expressing anxiety about their children's health demonstrated a higher level of satisfaction with care compared to parents who considered their children's health as good and/or did not worry about treatment outcomes regardless of the reason of the child's hospitalisation. Summing up, it should be concluded that our study results could also be affected by other factors not included in the study, such as a subjective perception of the child's health and the emotional state of the surveyed, which is supported by the findings of other scientific reports [29, 32].

The female study participants demonstrated a higher level of satisfaction with the nursing care organisation and empathy for a child compared to the male participants. Scientific reports do not provide clear results in this aspect, indicating a higher level of overall mothers' satisfaction with the professional- ism of nursing care [16] and a higher level of men's satisfaction with being informed by a nurse [11], or proving the absence of a relationship between respondents' sex and satisfaction with care $[1,19,28]$.

Moreover, the number of the respondents' children in a family was an important predictor of parental satisfaction with the professionalism of nursing care. The parents with 3 or more children were the most satisfied respondents regarding the services provided, while those with only 1 child demonstrated the lowest satisfaction level, which was consistent with the findings of other authors $[1,16]$. As in the study conducted by Smoleń and Ksykiewicz [16], no relationships between the respondents' education level and overall satisfaction with care professionalism were demonstrated. However, different study results were presented by Kruszecka-Krówka et al. [1] as well as Mucuk and Cimke [27], who confirmed a lower level of satisfaction with care among parents with a higher level of education.

In this study, the strongest relationships between the level of overall respondents' satisfaction with care professionalism and the satisfaction with nurses' attitude towards the parents as well as ensuring children the sense of security were demonstrated. According to Kinder [17], highly scored by parents, clinical competence of paediatric nurses has the strongest positive relationship with their intention to adhere to medical advice following discharge from hospital. In the opinion of Polish nurses, the quality of care mainly depends on the potential for ensuring patients the sense of security determined by working conditions, workload, and types of tasks [33], which is also supported by the results of research studies conducted in other countries [34, 35]. Scientific reports also provide evidence of higher levels of satisfaction with care regarding patients and their families in a situation of a friendly work environment and optimum nursing staff along with professional qualifications of nurses $[1,34,35]$. Multifactorial conditions of parental satisfaction with nursing care inspire further studies in this field, including paediatric surgical departments.

\section{Conclusions}

A high level of parental satisfaction with the professionalism of nursing care was observed. The optimization of nursing care is especially needed in the area of nurses' introducing themselves by name and surname. The determinants of overall satisfaction with the professionalism of nursing care or its selected specific criteria of care on paediatric surgical wards were as follows: the child's developmental stage, the reason for hospitalisation, the mode of admission to hospital, the parents' age, and the number of their children. The overall level of parental satisfaction with the professionalism of nursing care was most strongly determined by parental satisfaction with the 
nurses' attitude towards the child's family and with ensuring patients the sense of security during the hospitalisation period.

\section{Conflict of interest}

The authors declare no conflict of interest.

\section{References}

1. Kruszecka-Krówka A, Smoleń E, Cepuch G, Piskorz-Ogórek K, Perek M, Gniadek A. Determinants of parental satisfaction with nursing care in paediatric wards - a preliminary report. Int J Environ Res Public Health 2019; 16: 284.

2. Akbiyik A, Akin Korhan E, Kiray S, Kirsan M. The effect of nurses' leadership behavior on the quality of nursing care and patient outcomes. Creat Nurs 2020; 26: e8-e18.

3. Kraska RA, Weigand M, Geraedts M. Associations between hospital characteristics and patient satisfaction in Germany. Health Expect 2017; 20: 593-600.

4. Abdeldafie SY, Abraham BK. Parent's satisfaction with nursing care for pediatric gastrointestinal endoscopy patients in Khartoum State Public Hospitals Khartoum, Sudan. IOSR-JNHS 2017; 6: 96-102.

5. Afrashtehfar KI, Assery MKA, Bryant SR. Patient Satisfaction in medicine and Dentistry. Int J Dent 2020; 2020: 6621848.

6. Israel-Aina YT, Odunvbun ME, Aina-Israel O. Parental satisfaction with quality of health care of children with sickle cell disease at the University of Benin Teaching Hospital, Benin City. J Community Med Primary Health Care 2017; 29: 33-45.

7. Del Carmen Valls Martínez M, Ramírez-Orellana A. Patient satisfaction in the Spanish National Health Service: partial least Squares structural equation modeling. Int J Environ Res Public Health 2019; 16: 4886.

8. Georgoudi E, Kyriazis S, Mihalache A, Kourkouta L. Measurement of patient satisfaction as a quality indicator of hospital health services: the case of outpatient clinics in general hospital. SJPH 2017; 5: 128-135.

9. Hosseinian M, Mirbagher Ajorpaz N, Esalat Manesh S. Mothers' satisfaction with two systems of providing care to their hospitalized children. Iran Red Crescent Med J 2015; 17: e23333.

10. Karaca A, Durna Z. Patient satisfaction with the quality of nursing care. Nurs Open 2019; 6: 535-545.

11. Matziou V, Boutopoulou B, Chrysostomou A, Vlachioti E, Mantziou T, Petsios K. Parent's satisfaction concerning their child's hospital care. Jpn J Nurs Sci 2011; 8: 163-173.

12. Ustawa $\mathrm{z}$ dnia 6 listopada $2008 \mathrm{r}$. o prawach pacjenta i Rzeczniku Praw Pacjenta (Dz.U. 2019 poz. 1127, t.j. $\mathrm{z}$ dnia 17.06.2019).

13. Ustawa $z$ dnia 15 lipca 2011r. o zawodach pielęgniarki i położnej (Dz.U. 2011 Nr 174, poz. 1039).

14. Naczelna Rada Pielęgniarek i Położnych. Kodeks Etyki Zawodowej Pielęgniarki i Położnej Rzeczpospolitej Polskiej; https://nipip.pl/prawo/samorzadowe/ krajowy-zjazd-pielegniarek-i-poloznych/kodeks-etyki-zawodowej-pielegniarkii-poloznej-rzeczypospolitej-polskiej/.

15. Forsner M, Mörelius E, Hanberger L. Questionnaires to measure process and structure of quality indicators for pediatric nursing. Pediatr Qual Saf 2020; 6: e381.
16. Smoleń E, Ksykiewicz DA. Nurses' professionalism as a component of evaluation of parents/caregivers satisfaction with nursing care. Med Pr 2015; 66: 549-556.

17. Kinder FD. Parents' perception of satisfaction with pediatric nurse practitioners' care and parental intent to adhere to recommended health care regimen. Pediatr Nurs 2016; 42: 138-144.

18. Godsey JA, Houghton DM, Hayes T. Registered nurse perceptions of factors contributing to the inconsistent brand image of the nursing profession. Nurs Outlook 2020; 68: 808-821.

19. Willebrand M, Sjoberg F, Huss F, Sveen J. Parent's perceived quality of pediatric burn care. J Crit Care 2018; 43: 256-259.

20. Latour JM, van Goudoever JB, Duivenvoorden HJ, Albers MJ, van Dam NA, Dullaart E, van Heerde M, de Neef M, Verlaat CW, van Vught EM, Hazelzet JA. Construction and psychometric testing of the EMPATHIC questionnaire measuring parent satisfaction in the paediatric intensive care unit. Intensive Care Med 2011; 37: 310-318.

21. Smoleń E, Ksykiewicz DA. Satisfaction with chosen elements of nursing care at the department of paediatrics. Przedsiębiorczość i Zarządzanie 2014; 15: 215-228.

22. Kazimierczak M, Grzymała-Turzańska B, Kobiołka A. Specyfika opieki nad nieletnim pacjentem w oddziale chirurgii dziecięcej. Pielęg Pol 2016; 3: 403-414.

23. Bednarek A, Machul R. Uwarunkowania reakcji dzieci na hospitalizację $\mathrm{w}$ oddziale chirurgicznym - opinia rodziców i pielęgniarek. Przedsiębiorczość i Zarządzanie 2013; 14: 151-167.

24. Smoleń E, Ksykiewicz DA. Validation of polish version of the questionnaire for evaluation of parents/caregivers satisfaction with nursing care in a paediatric ward. Med Biol Sci 2015; 29: 41-46

25. Bednarek A. Dziecko w społeczeństwie. In: Pediatria i pielęgniarstwo pediatryczne. Zarzycka D, Emeryk A (eds.). Wydawnictwo Lekarskie PZWL, Warszawa 2020; 27-33.

26. Yoo SY, Cho H. Exploring the influences of nurses' partnership with parents, attitude to families' importance in nursing care, and professional self-efficacy on quality of pediatric nursing care: a Path Model. Int J Environ Res Public Health 2020; 17: 5452.

27. Mucuk S, Cimke S. Mothers' participation in the hospitalized children's care and their satisfaction. IJCS 2017; 10: 1643.

28. Sam CJ, Arunachalam PA, Manivasagan S, Surya T. Parental satisfaction with pediatric day-care surgery and its determinants in a tertiary care hospital. J Indian Assoc Pediatr Surg 2017; 22: 226-231

29. Franck LS, Ferguson D, Fryda S, Rubin N. The influence of family accommodation on pediatric hospital experience in Canada. BMC Health Serv Res 2017; 17: 561.

30. Divecha C, Tullu M, Deshmukh C, Minocha N. Assessment of parental satisfaction in a pediatric intensive care unit in a tertiary care centre. Pediatr Crit Care Med 2018; 19: 254.

31. Foster M, Whitehead L, Arabiat D, Frost L. Parents' and staff perceptions of parental needs during a child's hospital admission: an Australian study. J Pediatr Nurs 2018, 43: e2-e9.

32. Tsironi S, Koulierakis G. Factors associated with parents' levels of stress in paediatric wards. J Child Health Care 2018; 22: 175-185. 
33. Kózka M, Gabryś T, Brzyski P, Ogarek M, Cisek M, Przewoźniak L, Ksykiewicz-Dorota A, Gajda K, Brzostek T. Wybrane czynniki determinujące ocenę jakości opieki pielęgniarskiej w szpitalach pełniących stały dyżur. Wyniki projektu RN4CAST. Zdr Publ Zarz 2012; 10: 278-288.

34. Alloubani A, Akhu-Zaheya L, Abdelhafiz IM, Almatari M. Leadership styles' influence on the quality of nursing care. Int J Health Care Qual Assur 2019; 32: 1022-1033.

35. Nurmeksela A, Mikkonen S, Kinnunen J, Kvist T. Relationships between nurse managers' work activities, nurses' job satisfaction, patient satisfaction, and medication errors at the unit level: a correlational study. BMC Health Serv Res 2021; 21: 296.

\section{Address for correspondence:}

Dr. Agnieszka Kruszecka-Krówka

Nursing and Midwifery Institute

Faculty of Health Sciences

Jagiellonian University

Medical College

Krakow, Poland

Phone: +48 501615564

E-mail: agnieszka.kruszecka-krowka@uj.edu.pl 